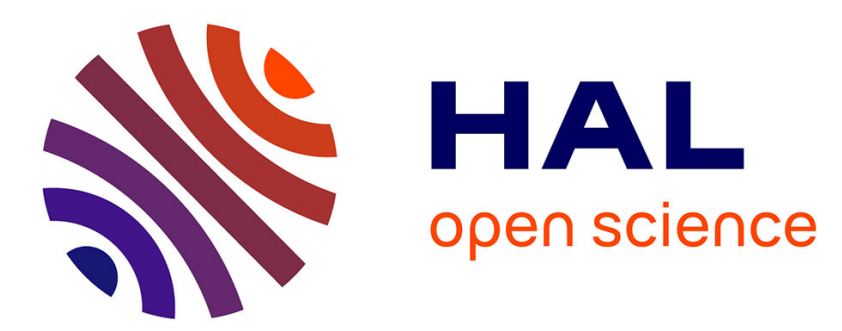

\title{
Characteristics of heads of seed-grown globe artichoke [Cynara cardunculus L. var. scolymus (L.) Fiori] as affected by harvest period, sowing date and gibberellic acid
}

Giovanni Mauromicale, Anita Ierna

\section{To cite this version:}

Giovanni Mauromicale, Anita Ierna. Characteristics of heads of seed-grown globe artichoke [Cynara cardunculus L. var. scolymus (L.) Fiori] as affected by harvest period, sowing date and gibberellic acid. Agronomie, 2000, 20 (2), pp.197-204. 10.1051/agro:2000119 . hal-00886000

\section{HAL Id: hal-00886000 https://hal.science/hal-00886000}

Submitted on 1 Jan 2000

HAL is a multi-disciplinary open access archive for the deposit and dissemination of scientific research documents, whether they are published or not. The documents may come from teaching and research institutions in France or abroad, or from public or private research centers.
L'archive ouverte pluridisciplinaire HAL, est destinée au dépôt et à la diffusion de documents scientifiques de niveau recherche, publiés ou non, émanant des établissements d'enseignement et de recherche français ou étrangers, des laboratoires publics ou privés. 


\title{
Characteristics of heads of seed-grown globe artichoke [Cynara cardunculus L. var. scolymus (L.) Fiori] as affected by harvest period, sowing date and gibberellic acid
}

\author{
Giovanni MAUROMICALE ${ }^{\mathrm{a}^{*}}$, Anita IERNA $^{\mathrm{b}}$ \\ ${ }^{a}$ Istituto di Agronomia generale e Coltivazioni erbacee, Università degli Studi di Catania, Via Valdisavoia 5, 95123 Catania, Italy \\ ${ }^{\mathrm{b}}$ Centro di studio sulle colture erbacee strategiche per l'ambiente mediterraneo del Consiglio Nazionale delle Ricerche, \\ Via Valdisavoia 5, 95123 Catania, Italy
}

(Received 19 July 1999; revised 15 November 1999; accepted 25 November 1999)

\begin{abstract}
Shifting harvest period from spring to autumn-winter-spring of seed-grown globe artichoke varieties, by a correct combination between sowing date and gibberellic acid- $\left(\mathrm{GA}_{3}\right)$ applications, may have effects on the suitability of heads (capitules) for the market. A two-year-study was carried out in Sicily (Southern Italy) to check the effects of harvest period (from November to April), sowing date (from 1 July to 20 August) and $\operatorname{GA}_{3}(0,1,2$ or 3) applications per plant on characteristics of heads of "Orlando", a new $\mathrm{F}_{1}$ seed-grown hybrid of globe artichoke [Cynara cardunculus L. var. scolymus (L.) Fiori]. Anticipating the harvest time from April to November, early sowing or 2 or 3 consecutive $\mathrm{GA}_{3}$ applications, generally decreased the head weight, increased the head length/width ratio, and the stalk length. These effects did not affect the market suitability of "Orlando" heads. They were less evident on heads of "Violetto di Sicilia", a traditional vegetatively propagated variety that usually produces heads from November to April.
\end{abstract}

Cynara cardunculus var. scolymus / globe artichoke / characteristics of heads / harvest period / sowing date / gibberellic acid

Résumé - Influence de la période de récolte, de la date de semis et de l'acide gibbérellique sur les caractéristiques des capitules de l'artichaut [Cynara cardunculus L. var. scolymus (L.) Fiori] multiplié par graines. Sur de nouveaux hybrides $\mathrm{F}_{1}$ d'artichaut, normalement à production printanière, la combinaison correcte entre la date de semis et les traitements à l'acide gibbérellique permet d'obtenir une production des capitules sans interruption de novembre à avril. Les facteurs responsables de cette anticipation des récoltes peuvent cependant modifier les caractéristiques des capitules en compromettant leur aptitude à la commercialisation. Dans deux localités différentes de la Sicile (Catane et

Communicated by Gérard Guyot (Avignon, France)

* Correspondence and reprints

agronomi@mbox.fagr.unict.it 
Syracuse), a été étudiée l'influence de la période de récolte, de la date de semis (du $1^{\text {er }}$ juillet au 10 août) et des traitements à l'acide gibbérellique $\mathrm{GA}_{3}(0,1,2,3$ applications à une concentration de $60 \mathrm{ppm})$ sur les caractéristiques des capitules de la variété Orlando, une nouvelle variété à multiplication par graines. L'anticipation de la période de la récolte d'avril à novembre, les semis précoces et deux ou trois applications avec $\mathrm{GA}_{3}$ ont, en général, diminué le poids des capitules et augmenté le rapport hauteur/largeur ainsi que la longueur de la hampe florale. Ces effets n'ont pas, toutefois, influencé l'aptitude à la commercialisation des capitules de la variété Orlando. L'effet des facteurs étudiés, les modifications des capitules ont été moins évidents sur la variété Violetto di Sicilia, qui produit naturellement ses capitules de novembre à avril.

Cynara cardunculus var. scolymus / artichaut / caractéristiques des capitules / période de récolte / date de semis / acide gibbérellique

\section{Introduction}

The globe artichoke [Cynara cardunculus L. var. scolymus (L.) Fiori] is a Mediterranean crop traditionally propagated vegetatively by basal stem pieces (stumps) or suckers in a dormant or active growing state. During the last ten years, seedgrown varieties have been developed [2, 3, 13]. Sown in summer, they complete their juvenile phase before winter, and produce during following spring $[4,8,10]$.

Recently, new seed-grown hybrids considerably reactive to gibberellic acid $\left(\mathrm{GA}_{3}\right)$, have been produced and tested [1, 11, Mauromicale unpublished data]. In these hybrids, the correct combination between sowing dates and $\mathrm{GA}_{3}$ treatments allows an uninterrupted harvesting from OctoberNovember to April, with a pattern of head production similar to that of "Violetto di Sicilia", a typical early vegetatively propagated Italian variety. The factors which are responsible for the notable anticipation in harvesting and the lengthening of production period, may affect the characteristics of heads. These effects may be enhanced by the changes in climatic conditions during growth and development of the heads, from autumn to spring. Foury [6] has shown that the appearance of heads from the same clone varies as a function of harvest period (autumn vs. spring) and latitude (North Africa/Spain vs. Provence).

The aim of this study was to evaluate the effects of sowing date, gibberellic acid and harvest period, on characteristics of heads of "Orlando", a new seed-grown $\mathrm{F}_{1}$ hybrid.

\section{Materials and methods}

Field trials were conducted in Sicily at Siracusa (1990-91) and Catania (1991-92). In these trials, the combinations between sowing date and $\mathrm{GA}_{3}$ treatments shifted part of the head harvest of "Orlando" $F_{1}$ hybrid from spring to previous autumn, while untreated control plants yielded in spring only. Details regarding localities, experimental design, $\mathrm{GA}_{3}$ application, plant material and cultivation techniques are reported in Mauromicale and Ierna [11]. Briefly, using Orlando hybrid, in Siracusa were investigated: two sowing dates (10 July and 10 August) and four $\mathrm{GA}_{3}$ treatments with $60 \mathrm{ppm}$ at $\mathrm{pH} 4$ (untreated plants, $\mathrm{GA}_{3}$ applied once at 8-leaf stage, twice at $8 / 15$-leaf stage and 3 times at 8/15/25-leaf stage). In Catania, were studied: three sowing dates ( 1 and 20 July and 10 August), three $\mathrm{GA}_{3}$ treatments (untreated plants, $\mathrm{GA}_{3}$ applied twice at 8/15-leaf stage and 3 times at $8 / 15 / 25$-leaf stage) and two varieties ("Orlando" $F_{1}$ and "Violetto di Sicilia" - VS, the main Italian vegetatively propagated variety).

\subsection{Data collection}

Heads (capitules) were harvested at marketing stage regardless of size. At this stage, the length of central flowers on the receptacle ranged between 2 and $3.5 \mathrm{~mm}$. From November to February harvests 
were made once a week and from March to April every 3-4 days. According to the custom of Italian farmers, all heads were harvested with the stalk. After harvesting, the stalk was removed (from the head) by cutting $0.5 \mathrm{~cm}$ under the receptacle. All heads were weighed and their maximum width (W) and length (L) measured. The length of the stalk was also measured.

In this study, only main and second order marketable heads were considered. About 1500 heads were checked individually.

\subsection{Data analysis}

Head length/width ratio, an important index of head shape, was calculated. This ratio is a relatively constant trait of each variety. It varies from $\leq 1$ in spherical/subspherical heads to $>1$ in long shaped types. A separate analysis of variance (ANOVA) was conducted for each single factor (harvest period, sowing date, $\mathrm{GA}_{3}$ application and variety) or interaction between the two factors. Means were separated by least significant difference (LSD) only when the F test of the ANOVA was significant at the 0.05 probability level. Polynomial effects up to second degree were made where appropriate to define the response of trend (linear or quadratic) between treatments and characteristics of heads.

\section{Results}

\subsection{Effects of harvest period}

In both years, harvest period significantly affected head characteristics. In general, "Orlando" head weight decreased as harvest period was advanced from April to November. This pattern was linear and with greater magnitude in "Orlando" than in "VS" (Fig. 1).

The two head size (length and width) values, which varied a little, and not always in the same way from November to February, showed a clear and significant increase from February to April.
The anticipation of harvest period linearly increased the L/W ratio of "Orlando" heads. However, this increase was very slight from April to March and from March to February determining also the significance $(\mathrm{P} \leq 0.05)$ of the quadratic effect of the regression. The $\mathrm{L} / \mathrm{W}$ ratio variation of heads of "VS" as a consequence of harvest season was little (did not exceed 10\%) and not linear (Fig. 1).

With the advance in harvest period, the trend in stalk length of "Orlando" decreased linearly in 1990-91, whereas it was not significant in 1991-92 (Fig. 1). On the contrary, the stalk length of "VS" increased linearly (Fig. 1).

\subsection{Effect of sowing date}

In both trials, the delay of sowing from 1 or 10 July to 10 August significantly increased head weight and width and reduced head length, and so the heads L/W ratio (Fig. 2). The increase in head weight was more evident in "Orlando" than in "VS" in 1991-92 (Fig. 2). The effects of sowing date on stalk length differed for years and varieties (Fig. 2). In 1990-91, at the later sowing, the stalk length of "Orlando" increased. During 1991-92, the second sowing shortened stalk in comparison with the two other sowings in "Orlando", while with a delay of sowing, the stalk length decreased in "VS".

\subsection{Effect of $\mathrm{GA}_{3}$}

In both trials, $\mathrm{GA}_{3}$ treatment significantly decreased the heads weight. This decrease was linear and significant for "Orlando" whereas it did not prove significant for "VS" (Fig. 3). GA 3 reduced particularly the heads width rather than length. As a consequence, the heads L/W ratio linearly increased with the increase in the number of $\mathrm{GA}_{3}$ applications (Fig. 3). Two or three applications of $\mathrm{GA}_{3}$ had opposite effects on stalk length of "Orlando" than on "VS". Stalk of the first variety was lengthened, while the second one shortened (Fig. 3). 

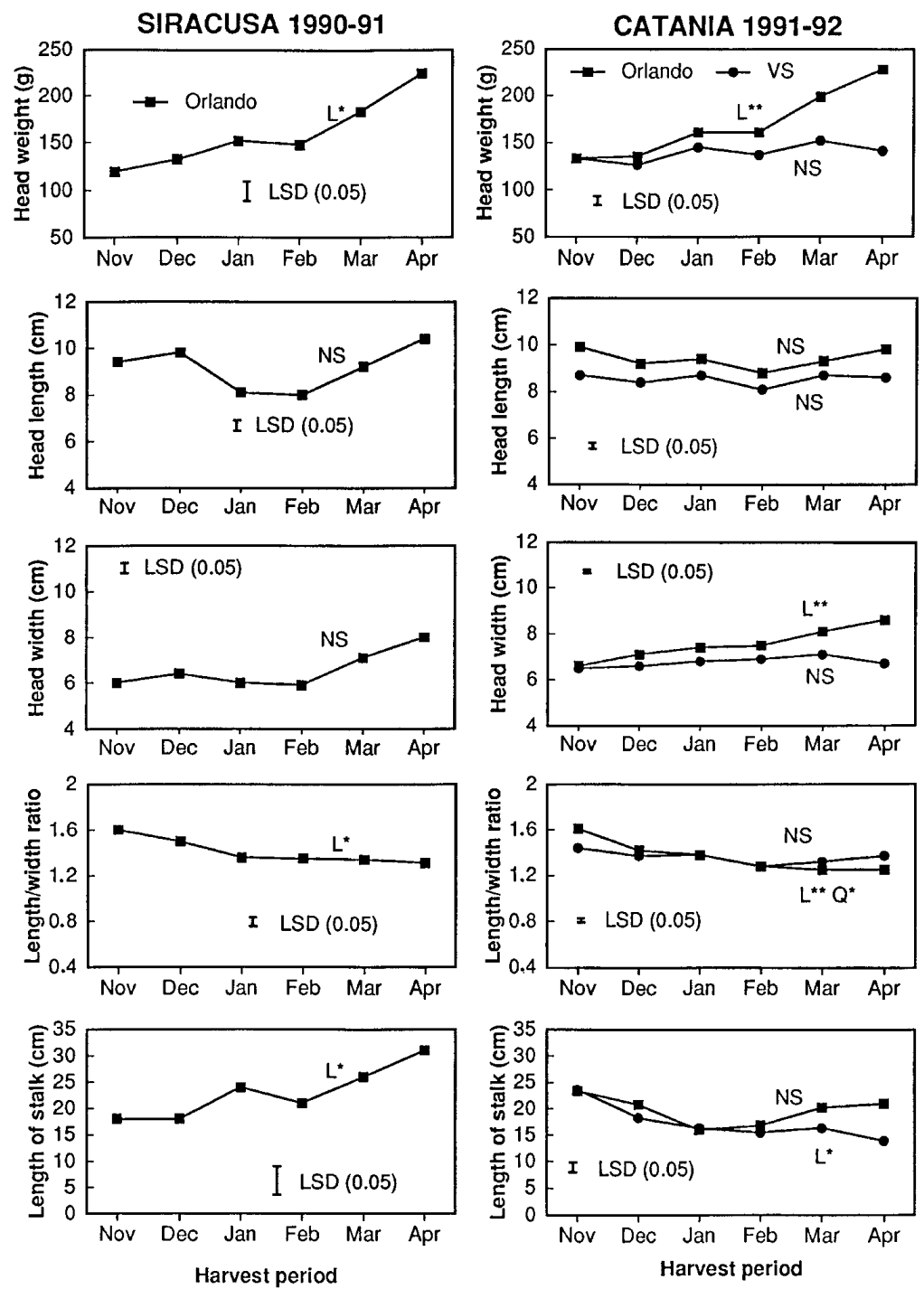

Figure 1. Effects of harvest period on characteristics of heads of seed-grown variety Orlando and vegetatively propagated variety VS, averaged over the other studied factors.

Significance levels for linear regression $(\mathrm{L})$ or quadratic $(\mathrm{Q})$ term. NS, *, $* *$, not significant or significant at $\mathrm{P} \leq$ 0.05 or 0.01 , respectively.

The effect of $\mathrm{GA}_{3}$ on weight and $\mathrm{L} / \mathrm{W}$ ratio of heads was weakened or not significant by the delay in sowing. In fact, in the first sowing, 3 applications of $\mathrm{GA}_{3}$ reduced the head weight to $45 \%$ (1990-91) and to 32\% (1991-92) in comparison with the untreated plants. In the last sowing, these reductions were only of 25 and $8 \%$, respectively (Fig. 4). In other words, while the weight of heads of untreated plants did not significantly differ between sowing dates, the weight of heads of plants treated 3 time of $\mathrm{GA}_{3}$ resulted in a significant decrease from July to August sowings (Fig.4).

The lengthening of heads (increase in $\mathrm{L} / \mathrm{W}$ ratio) due to $\mathrm{GA}_{3}$ was noteworthy and significant only in the first sowing (Fig. 4). 

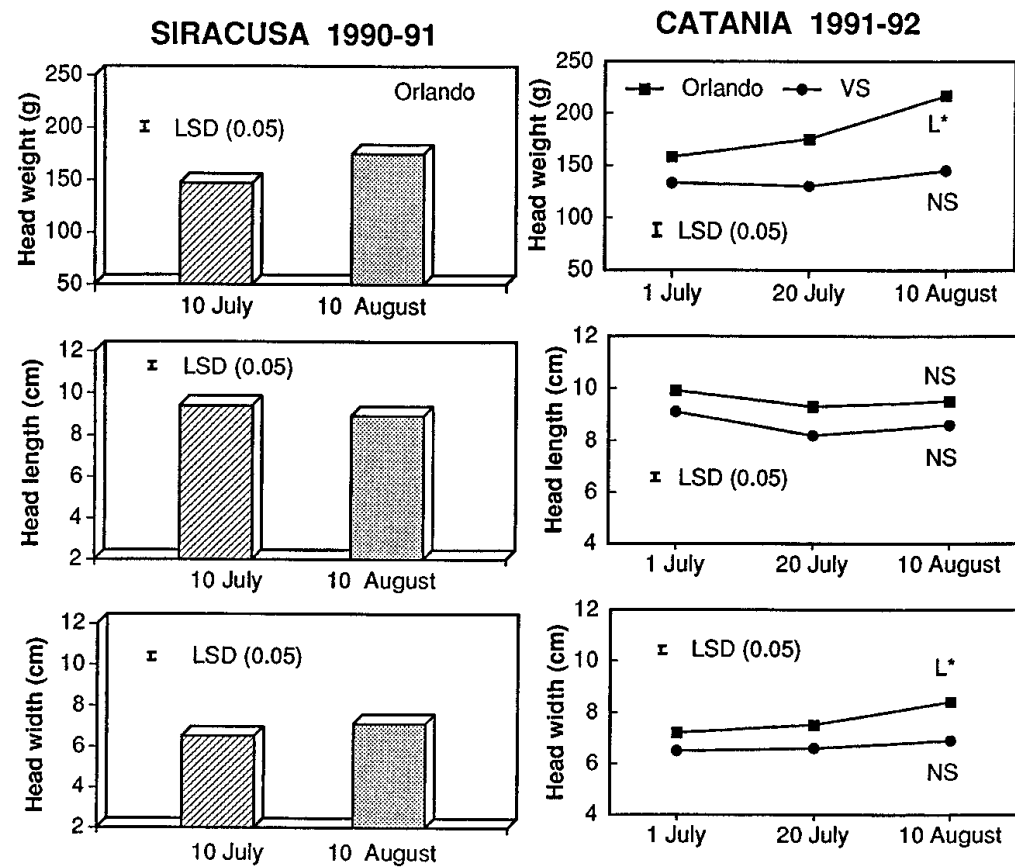

Figure 2. Effects of sowing dates on characteristics of heads of seed-grown variety Orlando and vegetatively propagated variety VS averaged over the other studied factors.

Significance levels for linear regression (L) or quadratic (Q) term. NS, *,**, not significant or significant at $\mathrm{P} \leq 0.05$ or 0.01 , respectively.
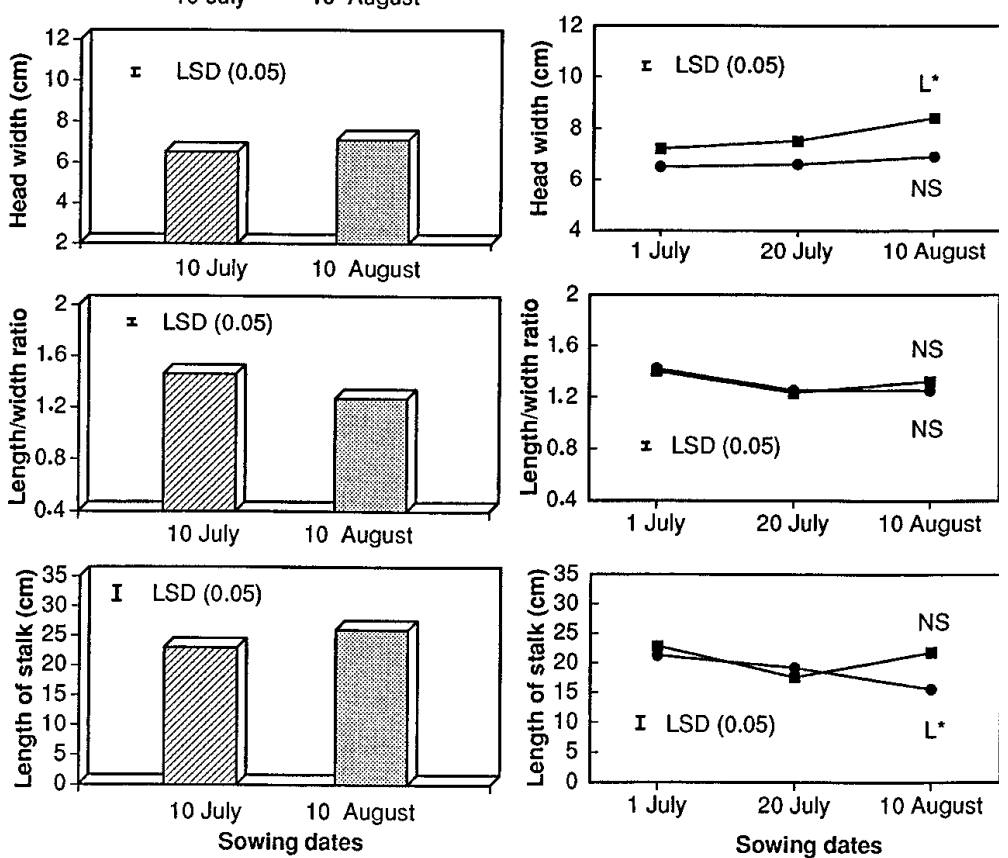

\subsection{Effect of variety}

The heads of "Orlando", compared with those of "VS", showed a significant higher weight (194 vs. $138 \mathrm{~g})$, length (9.5 vs. $8.2 \mathrm{~cm})$, width (7.5 vs. 6.4 $\mathrm{cm})$ and stalk length (21 vs. $17 \mathrm{~cm})$ (Tab. I).

\section{Discussion}

The results of this study demonstrate that harvest season, sowing date and $\mathrm{GA}_{3}$ application were able to modify some characteristics of heads of 

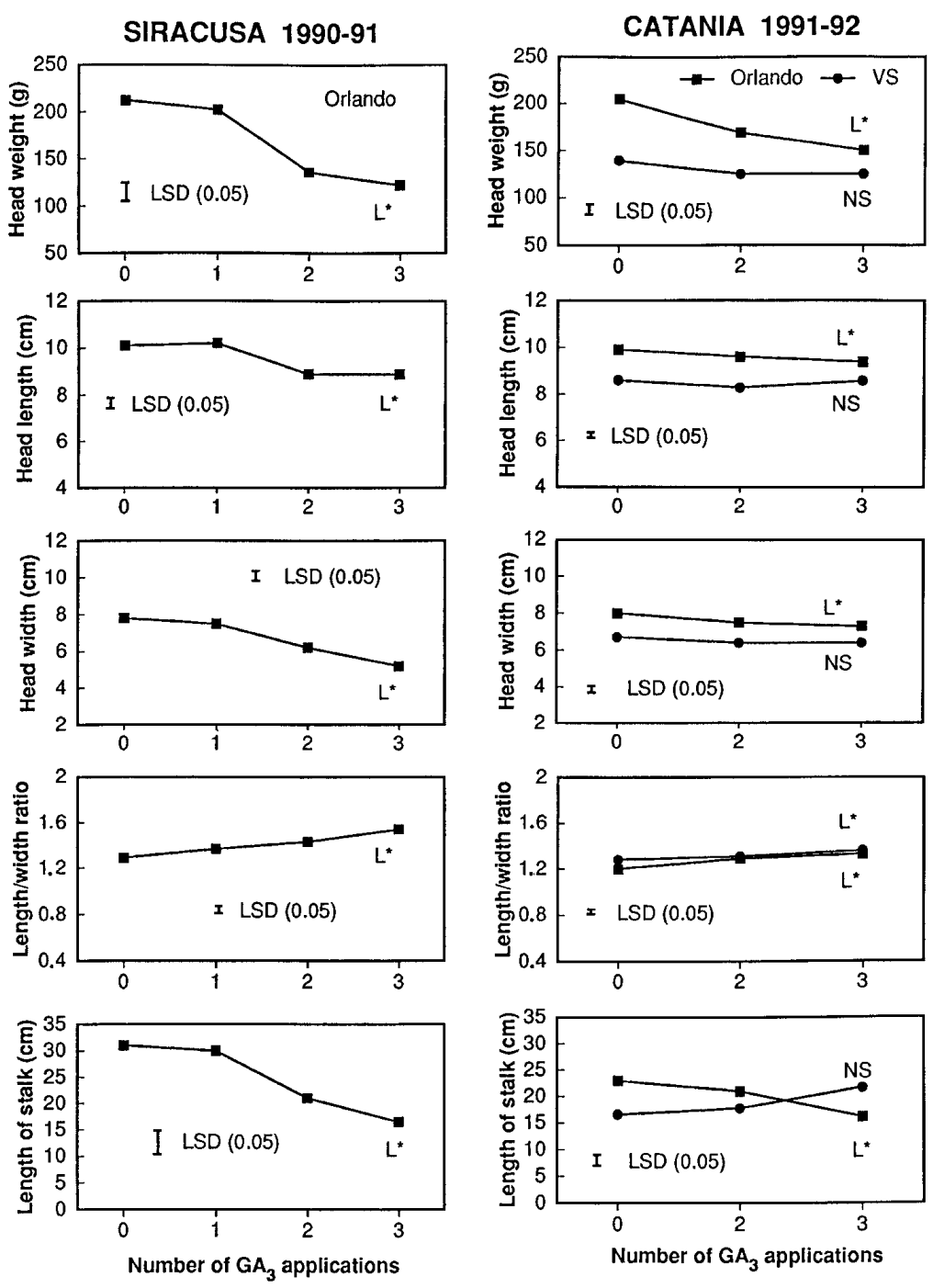

Figure 3. Effects of $\mathrm{GA}_{3}$ applications on characteristics of heads of seedgrown variety Orlando and vegetatively propagated variety VS averaged over the other studied factors.

Significance levels for linear (L) regression (quadratic was not significant). NS, *, not significant or significant at $\mathrm{P} \leq 0.05$, respectively.

Table I. Effect of variety on characteristics of heads, Catania 1991-92.

\begin{tabular}{lccc}
\hline Characteristics & Orlando & VS & Significance \\
\hline Head weight $(\mathrm{g})$ & 194 & 138 & $* *$ \\
Head length $(\mathrm{L}, \mathrm{cm})$ & 9.5 & 8.2 & $* *$ \\
Head width $(\mathrm{W}, \mathrm{cm})$ & 7.5 & 6.4 & $* *$ \\
L/W ratio & 1.27 & 1.31 & NS \\
Stalk length (cm) & 21.0 & 17.0 & $* *$ \\
\hline
\end{tabular}

$\mathrm{NS}=$ not significant, $* *$ significant at $\mathrm{P} \leq 0.01$.
"Orlando", a new globe artichoke variety propagated by seed. These modifications, however, did not affect the marketing suitability of the heads. Moreover, quality of heads gradually improves from November to April progressively becoming conform to the typical standard of the variety. In fact, shifting harvest period from April to November linearly decreased the weight of heads and the length of stalk and increased the L/W ratio. These effects are similar to those caused by the 
Figure 4. Effects of sowing dates $x$ $\mathrm{GA}_{3}$ applications on characteristics of heads.

Significance levels for linear (L) regression (quadratic was not significant). NS, *, not significant or significant at $\mathrm{P} \leq 0.05$, respectively.
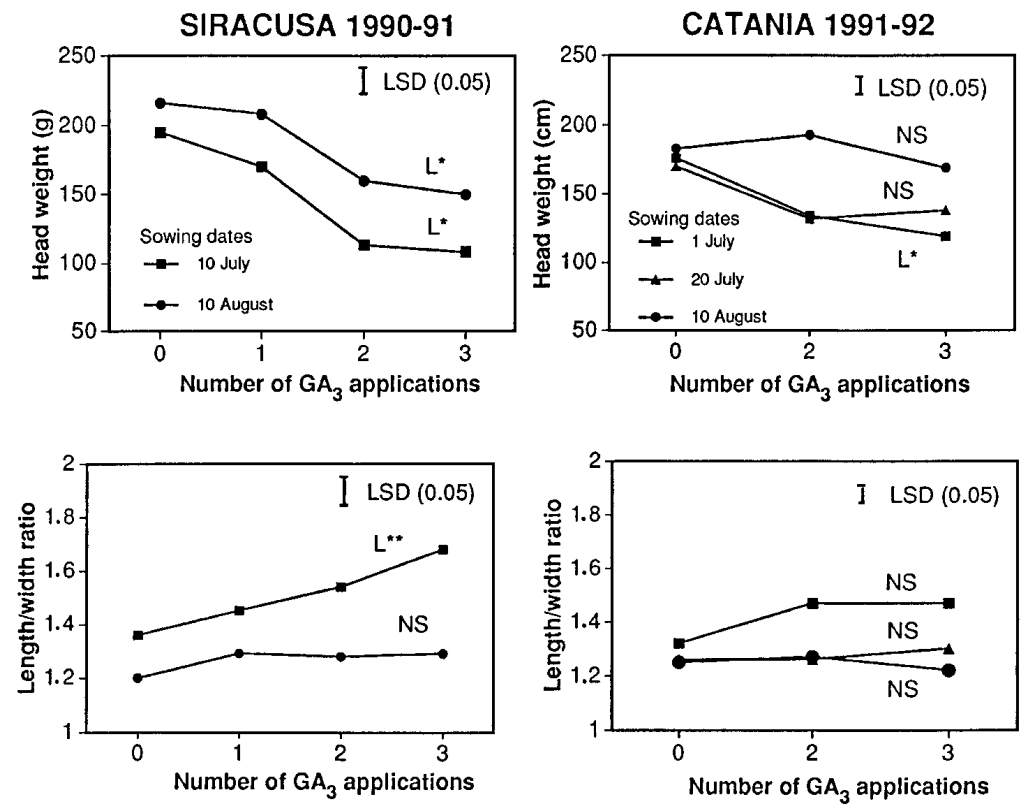

combination of $\mathrm{GA}_{3}$ treatments and early sowings $[1,11]$.

The response of "Orlando" was similar to that of "Romanesco", a vegetatively propagated Italian variety with spring production, which when treated with $\mathrm{GA}_{3}$ at an early stage, produces heads with low weight during late autumn - early winter [9]. For "VS" the effects of the studied factors were less evident because this traditional variety has been selected in Southern Italy for autumnal production, therefore the anticipation of harvesting is short. It seems that, as found in other research, when anticipation of harvesting is modest and therefore climatic conditions encountered during development of heads are fairly similar, the changes in characteristics of heads are probably few $[5,7,12]$. It is possible that the modifications of heads in "Orlando" noted in this study can be attributed to the lower temperature and the short days of late autumn and winter in comparison to those of spring, when the head development of untreated plants normally occurs.

It should not be excluded, in agreement with Basnizki and Goldschmidt [1], that reduction in head weight may be due to the limited amount of dry matter available following a relatively short vegetative phase. Given that the data recorded in this study do not allow to draw definitive conclusions on the causes of the changes in "Orlando" heads, further studies more specifically to this aim would seem opportune.

Acknowledgements: We thank R. Maugeri, B. Trombetta, A. Cuscunà and I. Longo for their technical assistance.

\section{References}

[1] Basnizki Y., Goldschmidt E.E., Further examination of gibberellin $\mathrm{A}_{3}$ effects on flowering of globe artichoke (Cynara scolymus L.) under controlled environment and field conditions, Isr. J. Plant Sci. 42 (1994) 159-166.

[2] Basnizki Y., Zohary D., A seed-planted cultivar of globe artichoke, HortSci. 22 (1987) 678-679.

[3] Basnizki Y., Zohary D., Breeding of seed-planted artichoke, Plant Breed. Rev. 12 (1994) 253-269. 
[4] Elia A., Paolicelli F., Bianco V.V., Effect of sowing date, plant density and nitrogen fertilizer on artichoke (Cynara scolymus L.): preliminary results, Adv. Hortic. Sci. 3 (1991) 119-122.

[5] Foury C., Essai d'application d'acide gibbérellique $\mathrm{GA}_{3}$ sur une culture d'artichaut de printemps (Cynara scolymus L.) cultivar "Blanc Hyérois", Ann. Amélior. Plantes 27 (1977) 411-426.

[6] Foury C., L'artichaut, in: Chaux C., Foury C. (Eds.), Productions Légumières, Vol. 2, Tec.-Doc. Lavoisier, Paris, 1994, pp. 405-438.

[7] Mangano G., Signorelli P., Azione di trattamenti con acido gibberellico, in fasi diverse dell' accrescimento delle piante, sulla produzione del carciofo, in: Atti $3^{\circ}$ Congr. Int. Carciofo, Bari, Laterza, Italy, 1981, pp. 565-579.

[8] Mauromicale G., Influenza del genotipo e dell'ambiente sul calendario di produzione del carciofo propagato per "seme", Inf. Agrario 50 (1994) 61-65.
[9] Mauromicale G., Aloisi M., Possibilità di anticipare la produzione del carciofo primaverile a mezzo dell'acido gibberellico, Ed. Tipolito Galatea, Acireale, Catania, Italy, 1988, p. 19.

[10] Mauromicale G., Basnizki Y., Cavallaro V., Primi risultati sperimentali sulla propagazione del carciofo (Cynara scolymus L.) per seme, Riv. Agron. 23 (1989) 417-423.

[11] Mauromicale G., Ierna A., Effects of gibberellic acid and sowing date on harvest time and yields of seedgrown globe artichoke (Cynara scolymus L.), Agronomie 15 (1995) 527-538.

[12] Patourel L., Foury C., Quelques effects de la gibberelline sur l'artichaut : intérêt pour les cultures traditionnelles, Bull. Tech. Inf. 369 (1982) 273-285.

[13] Pécaut P., Globe artichoke (Cynara scolymus L.), in: Kalloo G., Bergh B.O. (Eds.), Genetic Improvement of Vegetable Crops, Pergamon Press, Oxford, 1993, pp. 737-745. 